\title{
ETNOGRAFI KOMUNIKASI PERGESERAN MAKNA PESAN TRADISI PADUNGKU PASCA KONFLIK POSO DI SULAWESI TENGAH
}

\author{
Nofianti Lapasila ${ }^{1}$, Tuti Bahfiarti², Muhammad Farid ${ }^{3 *}$ \\ ${ }_{1,2,3}$ Program Studi Ilmu Komunikasi, Fakultas Ilmu Sosial dan Ilmu Politik \\ Universitas Hasanuddin Makassar \\ * Penulis korespondensi; Email: ${ }^{1}$ nofiantilapasila@ Gmail.Com, ${ }^{2}$ tutibahfiarti@yahoo.com, ${ }^{3}$ faridemsil@yahoo.com
}

\begin{abstract}
ABSTRAK
Padungku merupakan fase paling akhir dari siklus pertanian dalam budaya suku Pamona yang disebut ta'u, yakni proses yang dilakukan dari mengolah sawah/ladang sampai masa panen. Penelitian ini berjudul Komunikasi Ritual Tradisi Padungku Dalam Harmonisasi Sosial Pasca Konflik Poso di Sulawesi Tengah. Tujuannya mengidentifikasi pergeseran makna pesan tradisi Padungku pasca konflik, dan melihat makna pesan ritual-ritual dalam tradisi Padungku sebelum konflik. Penelitian ini merupakan penelitian jenis kualitatif memakai metode etnografi komunikasi yaitu menggambarkan dan menganalisis serta menjelaskan perilaku komunikasi dari kelompok sosial. Teknik pengumpulan data dilakukan dengan cara observasi, wawancara mendalam, dokumentasi dan studi pustaka. Selanjutnya data analisis menggunakan tehnik analisis data model interaktif Huberman yakni mengumpulkan data pada lokasi penelitian dengan menelaah hasil observasi dan wawancara lalu mereduksinya. Hasil penelitian menunjukan bahwa pergeseran makna pesan tradisi Padungku mempunyai dampak positif dalam harmonisasi sosial paska konflik di Poso Sulawesi Tengah. Makna mosintuwu; mangkoni-mangkeni; modero dalam tradisi Padungku mampu mejaga persatuan, kepedulian, dan harmonisasi, hingga tercipta sintuwu maroso (Bersatu kita kuat) di Tanah Poso.
\end{abstract}

Kata kunci: Komunikasi; Ritual; Tradisi Padungku; Harmoni Sosial; Pasca Konflik.

\begin{abstract}
Padungku is the last phase of the agricultural cycle in the Pamona culture called ta'u, which is the process carried out from cultivating the fields until the harvest period. This research is entitled Padungku Tradition Ritual Communication in PostPoso Conflict Social Harmonization in Central Sulawesi. The aim is to identify the shift in the meaning of the post-conflict Padungku traditional messages, and to see the meaning of the ritual messages in the Padungku tradition before the conflict. This research is a qualitative research using ethnographic communication methods, namely describing and analyzing and explaining the communication behavior of social groups. Data collection techniques are carried out by means of observation, in-depth interviews, documentation and literature study. Furthermore, the data were analyzed using Huberman's interactive model data analysis technique, namely collecting data at the research location by examining the results of observations and interviews and then reducing them. The results showed that the shift in the meaning of the traditional Padungku messages had a positive impact on post-conflict social harmony in Poso, Central Sulawesi. The meaning of mosintuwu; mangkoni-mangkeni; Modero in the Padungku tradition is able to maintain unity, care and harmony, so that it creates sintuwu maroso (We are strong united) in the Poso land.
\end{abstract}

Keywords: Communication; Rituals; Padungku tradition; Social Harmony; Post Conflict.

\section{PENDAHULUAN}

Kemajemukan budaya dan tradisi masyarakat di Indonesia menyebabkan perbedaan suku bangsa dengan karakteristik berbeda-beda. Tradisi atau budaya merupakan suatu warisan leluhur yang diteruskan dari generasi ke generasi secara turun temurun yakni cara hidup, cara berkembang dan di miliki bersama oleh suatu kelompok orang kemudian dijadikan kebiasaan. Untuk membangun suatu budaya diperlukan beberapa unsur yang sulit, yakni unsur agama, unsur politik, unsur adat istiadat, unsur bahasa, unsur perkakas, unsur pakaian, unsur bangunan, dan unsur karya seni.
Dalam sebuah masyarakat terdapat perbedaan karakter dengan masyarakat lainnya mengenai nilai-nilai budaya yang dijunjung tinggi. Nilai-nilai budaya dijadikan pedoman dalam menuntun perilaku individu-individu bersangkutan dalam berbagai aktivitasnya sehari hari. Kelompok masyarakat yang memiliki budaya dan tradisi akan beraktivitas sesuai dengan kebiasaan kebiasaan yang telah dilakukan secara turun temurun.

Mahluk sosial berarti kita bicara tentang manusia itu sendiri, itulah mengapa manusia tidak mampu hidup atau bertahan sendiri dari segi fisik maupun segi sosial budaya, dengan kata lain manusia saling 
membutuhkan untuk saling berkolaborasi dalam mencapai tujuan dan fungsi sosial lainnya. Dikarenakan dasar dari kehidupan sosial yaitu berjalannya fungsi-fungsi sosial dalam masyarakat itu sendiri. dengan fungsi sosial maka akan tercipta suatu kolaborasi yang baik antara sesama manusia, dengan kata lain, apabila fungsi sosial terjadi dalam kehidupan sosial maka manusia akan merasa lebih bermartabat. (Bungin, 2006).

Kota Poso merupakan Ibu Kota Kabupaten Poso terletak di Provinsi Sulawesi Tengah, Indonesia. Data tahun 2011 tercatat luas Kabupaten Poso 24.197 km2 dengan penduduk sebanyak 132.032 jiwa. Awalnya, penduduk yang berdiam di tana Poso ada dalam kekuasaan raja-raja. Adapun raja-raja yang memerintah di tana Poso antara lain; Raja Poso, Raja Mori, Raja Napu, Raja Una-una, Raja Tojo, dan Raja Bungku, yang dari kesemuannya ini tidak mempunyai hubungan sama sekali.

Enam wilayah tersebut tunduk pada 3 (tiga) pengaruh kerajaan. Wilayah selatan tunduk pada pemerintahan Raja Luwu (Palopo), untuk wilayah utara, mereka tunduk dibawah pemerintahan Raja Sigi (Donggala) Sulawesi Tengah, pada wilayah Timur (Bungku Kepulauan) di Morowali tunduk pada pemerintahan Raja Ternate. Oleh Pemerintah Hindia Belanda yang menguasai wilayah utara mulai menguasai Sulawesi tengah dan perlahan-lahan bertujuan melepaskan pengaruh Raja Luwu dan Raja sigi ditana Poso.

Pemerintah Hindia Belanda membagi wilayah dalam dua kekuasaan pemerintahan satunya adalah Keresidenan Manado Onderafdeeling / Kewedanan yakni wilayah Kolonodale dan Bungku, sedang pemerintahan raja-raja tetap mempertahankan wilayah kekuasaan kerajaan (self Bestuure-Gabieden) atau disebut wilayah kerajaan.

Wilayah Kerajaan tetap berpegang pada Peraturan Pemerintah Belanda disebut self Bestuure atau peraturan adat kerajaan (hukum adat) inilah yang menjadi awal mula pluralisme kebudayaan yang dibawa oleh masing masing Raja di Tana Poso.

Suku Pamona sendiri merupakan suku asli Tana Poso yang pendahulu mereka berasal dari tanah Salu Moge Kabupaten Luwu Timur, Sulawesi Selatan yakni orang-orang yang berasal dari Pemerintahan Pusat yang ditundukan oleh Macoa Bawalipu dari Wotu. Keadaan ini berlangsung hingga pemberontakan yang dilakukan Darul Islam (DI/TII) yang mengakibatkan mereka menyebar ke Sulawesi Tengah dan beberapa wilayah lainnya.
Pamona adalah singkatan dari Pakaroso Mosintuwu Napolanto (Pamona) nama ini mengacu pada persatuan beberapa etnis Suku Pamona. Masyarakat Suku Pamona di Poso tinggal di wilayah dataran tinggi seputaran Danau Poso. Etnis dalam suku pamona salah satunya adalah etnis Bare'e atau To Pamona.

Pamona kemudian menjadi sebuah suku bangsa yang disatukan oleh Pemerintahan Kolonial Belanda dan dideklarasikan di Tentena. untuk memperingati deklarasi tersebut diabadikanlah sebuah monument Watu Mpoga'a (Batu Perpisahan) sebagai pengingat asal usul. Suku Pamona berpencar pada dua wilayah di Kabupaten Poso yakni diwilayah pegunungan disebut To Pu'umboto (bagian tentena dan sekitar danau poso) dan wilayah pesisir pantai disebut To Pebato (wilayah bagian tojo una-una). Di sinilah tradisi Suku Pamona diperkenalkan menjadi kebiasaan dan dilanjutkan dari generasi ke generasi.

Tidak heran jika dalam satu wilayah terdapat suku pamona maka mereka akan membentuk komunitas rukun poso, berfungsi sebagai sarana perkumpulan etnis umum untuk terlibat dalam kegiatan mereka. Suku To Pamona mendiami hampir di seluruh wilayah di Kabupaten Poso, separuh di Tojo Una-una dan separuh di Morowali Sulawesi Tengah, bahkan beberapa masih ada di Kabupaten Luwu Timur, Sulawesi Selatan.

Bahasa Pamona digunakan oleh suku Pamona untuk saling berinteraksi satu sama lain. Dengan struktur bahasa yang terbilang unik dalam hal suku kata dan akar kata. Akar kata memiliki arti yang berbeda dengan awalan kata, begitu juga akhiran, dan tambahan sisipan serta imbuhan. Sebagai contoh akar kata Monco (Benar/True), ditambahkan imbuhan kamonconya (Sebenarnya/Actually), akhiran Moncou (Terayun/Swung), sisipan Monco-monco (sungguhsungguh/ Earnest).

Dikatakan unik karena bahasa pamona mempunyai banyak fase suku kata yang bisa dibolak-balik untuk membentuk arti yang berbeda, sebagai contoh: $M e-$ kaju (mencari kayu bakar/Finding firewood), Mokuja (sedang berbuat apa/what are you doing), Makuja (bertanya mengenai jenis kelamin bayi baru lahir/ inquiring the gender of a newborn baby), Makijo (bunyi teriakan riuh sebangsa monyet/sound of a primate shouting), Mokeju (Bersenggama/ Copulate).

Suku Pamona memiliki beberapa budaya yaitu tentang Kepercayaan (lamoa), Upacara Panen 
(Padungku), Upacara Kematian, Upacara Kelahiran (katiana), dan Upacara Perkawinan. Dari sekian banyak budaya tersebut, yang masih bertahan hingga saat ini yaitu Upacara Perkawinan dan Upacara Panen (Padungku).

Dalam penelitian yang dilakukan oleh Dosen Antropologi Fakultas Ilmu Sosial dan Ilmu Politik Universitas Tadulako, Siti Hajar N. Aepu dengan judul Padungku masih bertahan pada Etnis Bare'e di Desa Uedele Kecamatan Tojo Timur Kabupaten Tojo UnaUna (Aepu, 2014),

Dijelaskan bahwa Padungku adalah sebuah ritual adat turun temurun yang dilakukan untuk menghormati nenek moyang mereka. Konon menurut kepercayaan etnis Bare'e (Suku Pamona) di Desa Uedele Kecamatan Tojo Timur Kabupaten Poso ada seorang yang berdarah putih yang selalu mengenakan busana putih menikah dengan seorang putri dari kayangan dan mereka inilah yang mengawali ritual Padungku sebagai tanda ucapan syukur bagi sang pencipta ketika selesai masa panen. Sepeninggal sosok berdarah putih ritual ini terus dilanjutkan oleh keturunan berdarah putih yang masih hidup sampai sekarang pada etnis Bare'e di Desa Uedele. Ketika 9 hari setelah acara Padungku selesai maka keturunan darah putih akan membuka peti yang berisi baju serba putih peninggalan nenek moyang mereka (sosok berdarah putih yang menikah dengan putri kayangan) untuk memastikan apakah panen tahun depan berhasil atau gagal.

Etnis Bare'e percaya bahwa ketika peti dibuka tampak mengeluarkan cahaya silau keemasan maka dapat dipastikan panen tahun depan akan berhasil namun, ketika peti dibuka tapi tidak mengeluarkan cahaya dan isinya lusut maka dipastikan panen tahun depan akan gagal. Ritual ini kemudian menjadi tradisi turun temurun dan terus bertahan karena masyarakat uedele yang mayoritas punya pekerjaan sebagai petani. Pada penelitian ini sangat jelas bahwa Padungku merupakan tradisi turun temurun yang diwariskan nenek moyang dan juga sebagai ritual penghormatan terhadap nenek moyang.

Adapun Penelitian yang dilakukan oleh Puspitasari Rakhmat dengan judul Makna Pesan Simbolik Nonverbal Tradisi Mappadendang di Kabupaten Pinrang (Rahmat \& Fatimah, 2016),

Dijelaskan bahwa mappadendang mengingatkan kembali akan kosmologi kehidupan petani yang meyakini bahwa padi juga merupakan mahluk manusia bukan hanya sebagai sumber pangan, diyakini oleh masyarakat pedesaan jawa padi adalah sosok putri kayangan bernama Sangiyang Sri atau Dewi Sri yang sangat dihormati sebagai dewi padi. Dia mengorbankan dirinya menjadi padi agar stok pangan tetap tersedia bagi masyarakat.

Awalnya mappadendang dikenal sebagai adat panen yang merupakan kebiasaan para petani dari proses membajak, menanam, dan memasuki masa panen raya. Upacara Appalili merupakan hal pertama yang dilakukan masyarakat adat sebelum turun membajak sawah, kemudian dilakukan ritual Appatinro Pare/ Appabeni Ase sebelum melakukan penyemaian bibit padi yang dirangkai dengan ritual Massureq yakni membaca Meong Palo Karalae yang merupakan Epos Lagaligo tentang padi. Setelah masa panen tiba maka digelar ritual panen raya Katto Bokko yang diiringi dengan Kelong Pare. Setelah melalui semua proses ritual tersebut Barulah dilaksanakan Tradisi Mappadendang atau menumbuk padi muda.

Kabupaten Pinrang menggelar acara Mappadendang dibalai desa dengan makan bersama secara besarbesaran yang dihadiri oleh tua-tua, tokoh adat, tokoh agama, tokoh masyarakat dan para petani. Mappadendang tidak asing bagi suku bugis dimana tradisi ini diperingati sebagai tradisi hasil panen tiap tahunnya.

Mappadendang adalah pesta besar yang diadakan oleh suku Bugis di Kabupaten Pinrang. Acara ini adalah penumbukan padi pada lesung dengan tongkat yang besar. Komponen utama pada ritual ini adalah perempuan, pria, lesung, alu dan pakaian tradisional yang dikenakan oleh pria dan wanita yang menumbuk padi tersebut. acara ini merupakan bagian lain dari acara ritual hasil panen yaitu acara seni dalam memeriahkan tradisi Mappadendang.

Dalam tradisi seni Mappadendang seluruh komponen tadi akan menyajikan pertunjukan unik pria dan wanita yang telah memakai pakaian adat menumbuk alu dengan berbalas-balasan lalu akan terdengar irama teratur yang dimainkan dengan kelihaian para pemain yang biasa disebut dengan Pikkambona/Pakkambona. Dengan demikian interaksi simbolik terjadi dalam proses ritual dan dalam tradisi Mappadendang.

Seiring berjalannya waktu ritual ini sudah jarang dilaksanakan karena pengerjaannya telah berganti dari manusia ke mesin. Pada penelitian ini Mappadendang merupakan tradisi turun menurun yang terus menerus dipertahankan tradisi mappadendang juga meng- 
gambarkan kaitan suku Bugis dengan alam yang dianggap bukan hanya sebagai sumber penghidupan, akan tetapi menganggap alam sebagai bagian dari kehidupan mereka dan bertanggung jawab akan dampak buruk yang ditimbulkan alam apabila mereka tidak menjaga dan menghargai alam.

Simbol-simbol non verbal dalam tradisi Mappadendang menjadi pengingat bagi suku Bugis agar terus menjaga alamnya dan melestarikannya terlebih dari sektor padi sebagai sumber pangan nomor satu bagi pemenuhan kebutuhan masyarakat.

Dari kedua penelitian tersebut jelas bahwa tradisi Padungku adalah warisan nenek moyang yang menjadi kebiasaan turun temurun, akan tetapi tradisi Padungku atau upacara panen pada setiap wilayah itu berbeda. Tradisi disesuaikan dengan filosofi masingmasing daerah. Perbedaan terlihat dari ritual yang dilakukan dan makna pesan simbolik yang ada didalamnya.

Kali ini peneliti melakukan penelitian tradisi Padungku di Kabupaten Poso. penulis tertarik meneliti makna pesan tradisi Padungku dalam harmonisasi sosial masyarakat pasca konflik di Kabupaten Poso.

Tradisi Padungku dilaksanakan setiap masa panen. Itulah tradisi Padungku yang dilakukan suku Pamona secara terus menerus sebelum masuknya agama di Tana Poso. Agama yang dianut suku Pamona adalah Kristen (Mayoritas), Islam, dan Agama Tua (adat leluhur).

Agama Kristen ditana poso yang dibawa oleh Dr. N. Adriani (1892) dan Dr. Albertus Cornelius Kruyt (1895) menjadikan penduduk suku Pamona mayoritas beragama Kristen yaitu penduduk yang berdomisili di wilayah pegunungan, seperti Tentena dan sekitarnya. (Hasrullah, 2009).

Masuknya agama Islam di Tana Poso disebarkan oleh para saudagar - saudagar Bugis yang datang dibagian pesisir Kabupaten Poso yang merupakan jalur perdagangan melalui laut. Penduduk yang berdomisili dipesisir Kabupaten Poso antara lain: Poso pesisir, Tojo, Una-una, Ampana, Togean, Bungku dan Kolonodale. (Hasan, 2004).

Penduduk yang menerima dampak penyebaran agama sebagian dari mereka bukanlah petani suku Pamona saja, diantaranya ada beberapa suku yang telah lama berdiam di Kabupaten Poso yakni peninggalan raja-raja terdahulu seperti suku mori, suku toraja, dan beberapa suku lainnya.
Paska konflik tahun 1998 Tradisi Padungku hanya dilestarikan oleh kaum Nasrani Kabupaten Poso. Jadwal perayaan Padungku diatur oleh majelis klasis tiap wilayah. majelis berkoordinasi dengan perangkat masing masing Desa, Kelurahan dan Kecamatan, sehingga jadwal Padungku terus dilaksanakan setiap tahunnya.

Pasca konflik ritual Padungku dilakukan dengan melihat waktu tanam yang baik, yaitu dengan melihat musim tahunan. Dalam setahun dilakukan dua sampai tiga kali penanaman dimulai bulan Maret, kemudian lanjut bulan juli dan bulan Oktober.

Kegiatan pengolahan persawahan dilakukan dengan gotong royong atau mesale secara kekeluargaan ataupun menggunakan pekerja upahan. Hasil pertama panen dibawa untuk buah sulung di rumah ibadah sebagai persembahan kepada sang pencipta. Padungku digelar sekali dalam setahun pada masa panen kedua yaitu pada bulan September atau Oktober.

Tradisi sebagaimana dipahami adalah merupakan Adat atau kebiasaan yang berlangsung dari generasi ke generasi, tradisi merupakan warisan budaya dari para pendahulu yang masih dilakukan sampai hari ini sebagai bentuk kepercayaan akan suatu filosofi yang terus dikembangkan disuatu daerah.

Padungku di Kabupaten Poso merupakan fase paling akhir dari siklus pertanian dalam budaya suku Pamona disebut ta'u yakni proses yang dilakukan mulai dari mengelola sawah ladang hingga masa panen.

Tahapan dimulai dengan melakukan pengamatan terhadap letak betu'e Tamangkapa (Rasi Bintang Belantik atau Orion). Ketika matahari mulai terbenam dan tampak letak betu'e tamangkapa meninggi, maka dipastikan saat itulah waktu terbaik untuk Mombakati atau memulai pekerjaan bertani.

Mengawali kegiatan bercocok tanam dilakukan ritual menaikan doa-doa untuk menanam dan doa pengakuan dosa oleh salah seorang wanita penganjur pertainan disebut dengan Tadulako Mpojamaa kemudian ia akan membawa dahan tanaman yang disebut Pokae untuk ditancapkan ketanah.

Setelah proses ritual selesai maka dimulailah proses pembukaan lahan dan pembersihan lahan dengan membersihkan lokasi yang akan dijadikan ladang 
pertanian secara gotong royong yang disebut Mesale. Kegiatan Mesale ini terus dilakukan pada proses menanam hingga merawat tanaman. Masa jeda antara proses pengerjaan hingga panen disebut eua.

Untuk memastikan tanaman siap dipetik tua tua adat (Tadulako Mpojamaa) akan melakukan ritual keliling dengan berjalan mengitari persawahan/perkebunan kemudian memilih empat rumpun bulir padi sekaligus dengan daunnya yang dianggap baik. Bulir padi tersebut diikat dan ditaruh pada sebuah tempat yang disebut Bingka lalu ditutupi dengan kulit kayu yang disebut Fuya dengan maksud agar jiwa padi terikat dibumi dan tidak kaget ketika dipotong.

Paska konflik tahun 1998 Tradisi Padungku hanya dilestarikan oleh kaum nasrani Kabupaten Poso. Jadwal perayaan Padungku diatur oleh majelis klasis tiap wilayah. majelis berkoordinasi dengan perangkat masing masing Desa, Kelurahan dan Kecamatan, sehingga jadwal Padungku terus dilaksanakan setiap tahunnya. Tradisi Padungku menjadi agenda perayaan tahunan di Kabupaten Poso. Perhatian Pemerintah dalam melestarikan tradisi Padungku menandakan Padungku mempunyai Filosofi yang sangat dalam dan berperan penting dalam pemulihan keadaan poso paska konflik bagi masyarakat Kabupaten Poso.

Clifford Geertz mengartikan suatu budaya merupakan nilai yang secara historis punya karakter tersendiri yakni satu sistem dari konsep ekspresi suatu komunikasi yang berlangsung antar sesama manusia yang terkandung makna dan terus berkembang seiring peningkatan pengetahuan manusia dalam perjalanan hidup manusia tersebut. Dengan demikian, pengertian budaya dapat didefinisikan dalam sebuah nilai, kebiasaan dan kepercayaan yang dengan perjalanan waktu akan terus berkembang. (Martin \& Nakayama, 1997).

Penulis menganggap penelitian ini penting untuk dilaksanakan, sebab penulis melihat bahwa tradisi Padungku sangat berperan dalam menciptakan harmonisasi sosial masyarakat setelah konflik di Kabupaten Poso.

Penelitian ini, melihat bagaimana mengidentifikasi simbol-simbol tradisi Padungku dalam upaya harmonisasi sosial masyarakat setelah konflik dan bagaimana makna pesan tradisi Padungku dalam upaya harmonisasi sosial masyarakat sebelum konflik di Kabupaten Poso. dalam penelitian sebelumnya mengenai kajian tradisi lebih membahas tatacara ritual suatu daerah, untuk itu peneliti ingin mengetahui bagaimana tradisi Padungku di kabupaten Poso mampu menciptakan harmoni sosial masyarakat pasca konflik di Kabupaten Poso.

\section{KAJIAN PUSTAKA}

Schemerhorn, menjelaskan dalam bukunya: Managing Organization Behavior, menyatakan komunikasi sebagai suatu proses antar personal dalam menerima dan mengirim simbol - simbol yang dianggap berarti bagi kepentingan mereka.

Hovlan menyatakan kurang lebih dua definisi komunikasi, dikatakan komunikasi adalah suatu proses dalam mengubah perilaku orang lain (communication in the process to modify the behavior of other individuals). Selanjutnya dia mengemukakan komunikasi adalah sebuah upaya sistematis dalam merumuskan secara tegas asas-asas penyampaian informasi serta membentuk pendapat dan sikap. (Hanani, 2017).

Adapun fungsi komunikasi yang diungkapkan dalam (Cangara, 2016) adalah kemampuan yang dapat digunakan untuk memenuhi tujuan tertentu. Secara klasik fungsi komunikasi ditujukan untuk:

1) Memberi informasi

2) Menghibur

3) Mendidik

4) Membentuk opini public.

Informasi dalam komunikasi berfungsi memberikan informasi kepada individu ataupun kelompok dalam mengambil suatu keputusan dengan cara menyampaikan data guna mengenai dan menilai pilihan alternatif.

Manusia memiliki keistimewaan dari mahluk lainnya. Manusia mampu menciptakan simbol-simbol dan mengartikan gejala-gejala yang ditimbulkan oleh alam disekitarnya. Kemampuan manusia menciptakan simbol dapat membuktikan bahwa manusia sudah memiliki kebudayaan yang tinggi dalam berkomunikasi mulai dari dari simbol sederhana seperti bunyi dan isyarat.

Susanne K. Langger menyatakan kebutuhan simbolisasi atau penggunaan lambang merupakan salah satu kebutuhan pokok manusia dalam berkomunikasi, dan salah satu yang merupakan sifat dasar manusia adalah kemampuan menggunakan simbol Wiemen dan Walter (Johannesen 1996:46) dalam (Mulyana, 2013).

Manusia dapat saling berinteraksi karena makna yang disepakati bersama. Makna sendiri timbul dari hubungan khusus antar kata (sebagai simbol verbal) dan manusia. Makna tidak melekat pada kata-kata, akan tetapi kata-kata dapat membangkitkan makna dalam pikiran seseorang. Tidak ada hubungan lang- 
sung antara sumber dengan simbol yang digunakan untuk merepresentasikan sesuatu.

Dalam setiap simbol terkandung sebuah makna. Devito mengatakan bahwa pemberian makna merupakan proses yang aktif karena makna diciptakan dengan kerja sama antara sumber dan penerima, pembicara dan pendengar, penulis dan pembaca. Dengan adanya interaksi antar manusia maka terbentuklah simbol-simbol yang memiliki makna (Devito, 1997).

Komunikasi verbal menggunakan kata-kata menandakan manusia memiliki kemampuan dalam mengungkapkan perasaan, emosi. Atau ide dalam menyampaikan data dan informasi sekaligus bertukar perasaan dan pikiran dengan satu kata atau lebih. (Bahfiarti, 2019).

Komunikasi non verbal adalah suatu hal yang penting dalam interaksi manusia karena dapat menciptakan kesan. Contonya ketika orang melakukan wawancara pekerjaan secara tidak langsung ekspresi seseorang dapat menjelaskan apa yang ada dalam pikirannya.

Dalam komunikasi simbol sering diartikan sebagai lambang. Asal kata simbol berasal dari Yunani "SymBallein" artinya melemparkan bersama suatu (benda, perbuatan) yang terkait dengan suatu ide. simbol adalah lambang dari suatu bentuk yang lain diluar perwujudan bentuk simbolik itu sendiri (Sobur, 2013).

Simbol dapat dibedakan dalam beberapa bentuk:

1) Simbol-simbol universal, berkaitan dengan arketipos, misalnya tidur sebagai lambang kematian.

2) Simbol cultural yang dilatarbelakangi oleh kebudayaan tertentu, misalnya keris dalam kebudayaan jawa.

3) Simbol individual yang biasanya dapat ditafsirkan dalam konteks keseluruhan karya seorang pengarang.

Beamer dan Varner mencatat bahwa komunikasi non verbal dapat dipengaruhi oleh beberapa faktor termasuk latar belakang budaya, latar belakang sosial ekonomi, latar belakang pendidikan, usia, gender, dan kecenderungan pribadi. Dalam budaya tertentu tidak semua orang melakukan tindakan non verbal yang sama untuk itu harus evaluasi yang hati hati sebelum menyimpulkannya (Samovar, Porter, \& McDaniel, 2010).
Adapun fungsi komunikasi yang diungkapkan dalam (Cangara, 2016) adalah kemampuan yang dapat digunakan untuk memenuhi tujuan tertentu. Secara klasik fungsi komunikasi ditujukan untuk:

1) Memberi informasi

2) Menghibur

3) Mendidik

4) Membentuk opini public.

Sedangkan Fungsi komunikasi dalam (Khairani, 2015) adalah:

1) Kendali dalam komunikasi berfungsi untuk mengendalikan perilaku anggota dengan beberapa cara. Pada tiap kebudayaan terdapat wewenang dan garis panduan formal yang harus menjadi perhatian seluruh anggotanya.

2) Motivasi dalam komunikasi sangat membantu dalam perkembangan motivasi anggotanya dengan menjelaskan apa yang harus mereka lakukan dan apa yang harus mereka kerjakan untuk memperbaiki sikap tiap anggotanya.

3) Pengungkapan Emosional yang terjadi dalam komunikasi merupakan mekanisme fundamental yakni bagaimana anggota dapat menunjukan kekecewaan begitu juga rasa puas mereka.

4) Informasi dalam komunikasi berfungsi memberikan informasi kepada individu ataupun kelompok dalam mengambil suatu keputusan dengan cara menyampaikan data guna mengenai dan menilai pilihan alternatif.

Selanjutnya, Goran Hadebro dalam (Cangara, 2016) mengemukakan bahwa media komunikasi berfungsi sebagai berikut:

1) Menciptakan perubahan suasana melalui nilainilai baru dalam mengubah sikap dan perilaku kearah modernisasi.

2) Mengedukasi masyarakat dengan keterampilan baru.

3) Berfungsi melipat gandakan ilmu pengetahuan dalam penyebarannya menggunakan media komunikasi.

4) Mengefisiensi tenaga dan biaya terhadap mobiletas seseorang.

5) Meningkatkan aspirasi seseorang saat menerima informasi dari media komunikasi.

6) Meningkatkan partisipasi dalam pengambilan keputusan mengenai perihal yang menyangkut orang banyak.

7) Ditemukannya nilai baru dalam keharmonisan pada kondisi tertentu.

8) Meningkatkan rasa kebangsaan dengan informasiinformasi mengenai kepedulian terhadap bangsa dan Negara. 
9) Mendorong aktivitas politik seseorang dengan mengambil bagian dalam penentuan kebijakan publik melaui opini yang dikemukakan.

10) Mengubah struktur kekuasaan dalam suatu masyarakat.

11) Sarana dalam membantu program pembangunan dengan keikutsertaan dalam agenda-agenda public.

12) Mendukung pelaksanaan pembangunan dibidang ekonomi, sosial, politik suatu bangsa untuk kesejahteraan bersama.

Adapun menurut Effendy setiap manusia berkomunikasi dengan maksud dan tujuan tertentu, ia menjelaskan bahwa ada beberapa tujuan komunikasi (Effendy, 2017), antara lain:

1) to change the attitude (Mengubah sikap)

2) to change the opinion (Mengubah Opini)

3) to change the behavior (Mengubah Perilaku)

4) to change the society (Mengubah Masyarakat).

\section{METODE PENELITIAN}

Metode yang digunakan peneliti dalam kegiatan ilmiah ini adalah metode kualitatif studi etnografi komunikasi dimana peneliti menggambarkan dan menjelaskan hubungan dari kategori-kategori dan data yang diperoleh dalam komunikasi makna pesan tradisi Padungku dalam upaya harmonisasi paska konflik di Kabupaten Poso.

Sumber data dan informasi peneliti kumpulkan dari wawancara langsung dengan informan sesuai kesepakatan sebelumnya dengan informan, wawancara dilakukan menggunakan pedoman wawancara (guide interview) tentang inti dari masalah yang akan peneliti ketahui. Adapun informan dalam penelitian ini berjumlah 5 (lima) orang informan. Pemilihan informan ditentukan dengan cara purposive sampling yaitu memilih secara acak informan yang dianggap mampu memberikan informasi yang akurat dan jelas mengenai inti permasalahan. Tehnik pengumpulan data dilakukan dengan cara melakukan pengamatan langsung mengenai fenomena tradisi Padungku yang terjadi dilokasi penelitian bertepatan penulis merupakan masyarakat Kabupaten Poso dan mengupdate informasi baru yang diperoleh dari wawancara mendalam dengan informan mengenai tradisi Padungku. Tahap selanjutnya peneliti melakukan proses reduksi data dan penarikan kesimpulan.

\section{HASIL DAN PEMBAHASAN}

Makhluk sosial disebut juga makhluk komunikasi, dalam menjalani kehidupan manusia berinteraksi menggunakan berbagai macam simbol dan kode yang diciptakan manusia tersebut atau yang alami.

Manusia memiliki keistimewaan dari mahluk lainnya. Manusia mampu menciptakan simbol-simbol dan mengartikan gejala-gejala yang ditimbulkan oleh alam disekitarnya. Kemampuan manusia menciptakan simbol membuktikan bahwa manusia telah memiliki kebudayaan yang tinggi dalam berkomunikasi mulai dari simbol sederhana seperti bunyi dan isyarat.

Di Kabupaten Poso orang mengenal Padungku sebagai syukuran hasil panen. Untuk mengetahuinya, terlihat jika dalam suatu wilayah telah rampung dalam memanen padi disawah artinya wilayah tersebut melaksanakan tradisi Padungku ada kegiatan masyarakat yang sedang berlangsung terjadi diwilayah tersebut, spontanitas warga bertandang untuk sekedar silahturahim atau berjumpa sanak saudara. Terlihat juga bagaimana masyarakat ramai saling bahu membahu, kemudian berkunjung kerumahrumah warga untuk mencicipi hidangan dirumahrumah warga dan ada tarian modero dimalam hari sebagai penutup kegiatan. Tradisi Padungku merupakan wadah bagi masyarakat pasca konflik untuk kembali berkomunikasi langsung, saling bertatap muka dan saling menyapa sehingga tercipta keharmonian.

Salah satu simbol dari tradisi Padungku adalah Mosintuwu yaitu sikap bahu-membahu dalam segi materi mapun tenaga dalam membangun persatuan untuk menciptakan masyarakat yang kuat sekaligus dari sudut adat dan budaya yakni mempertahankan budaya sintuwu maroso poso (bersatu kita kuat) interaksi yang terjalin ketika mosintuwu membuat situasi yang dahulunya mencekam menjadi lebih cair dan hangat karena pembauran yang terjadi ketika berinteraksi. Seperti hasil wawancara bersama bue tini berikut dalam wawancara mendalam dengan nenek Tini 14 Februari 2020)

"kalo mosintuwu itu maknanya hidup saling membantu, hidup saling menolong, hidup saling menghidupi. Dan apa yang kita beri dalam wujud mosintuwu itu kita tidak pernah mencatat dikertas atau dalam hati kita, awas kalo kita kase seratus ribu, kamu cuma kase lima puluh ribu, butul butul (benar-benar) kita mendukung orang yang membutuhkan bantuan. (Diambil dari recmp3 durasi 36:37.87. 


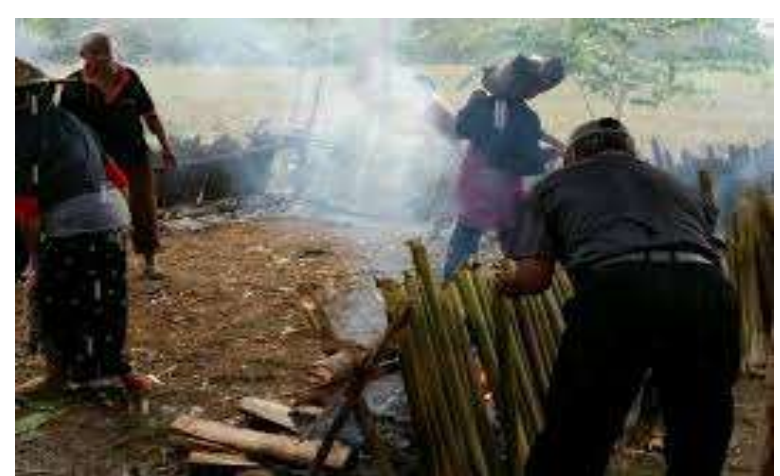

Gambar 1. Bahu-membahu pada perayaan Padungku

Selain tradisi mosintuwu ada juga tradisi mangkoni mongkeni. Tradisi mangkoni mongkeni dibudayakan dalam masyarakat suku pamona dimaknai sebagai rasa syukur dan terima kasih kepada sang pencipta yang diwujudkan dengan kepedulian sosial terhadap sesama umat manusia dimuka bumi biasanya dengan memberikan bekal kepada tamu untuk dibawa pulang. Dengan harapan sang pencipta menerimanya dan kembali memberikan sesuatu yang baik dalam kehidupan ini.

Berikut kutipan wawancara mendalam dengan nenek Tini 14 Februari 2020) "makanya dibilang abis mangkoni mongkeni nah itu tradisi itu memang dilakukan. Makanya ketika memasak tidak dibilang kira kira sepuluh orang datang eh nasi untuk sepuluh porsi saja, tidak, harus dimasak lebih karna sepuluh orang yang datang itu dia mo makan sepuluh orang itu kecuali dia suami istri misalnya, tapi kalo masingmasing beda rumah ya mungkin Sembilan ato tetap sepuluh disiapkan untuk cendramata mo dibawa oleole buah tangan. (Diambil dari recmp3 durasi 34:55.32

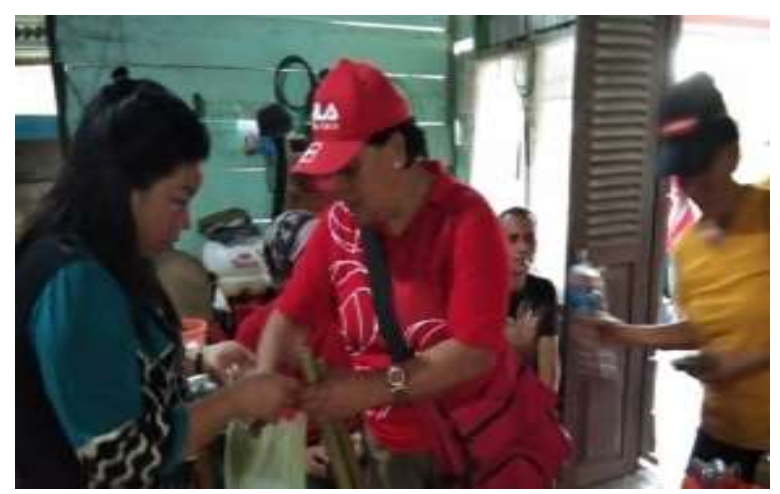

Gambar 2. Memberikan bingkisan kepadatamu untuk dibawa pulang.

Adapun puncak acara dari pesta perayaan Padungku yaitu dengan melakukan tradisi modero sebagai tarian suku pamona tarian dero didominasi oleh kaula muda merupakan simbol kegembiraan dan sukacita dengan bergandengan tangan akan terjadi interaksi saling komunikasi yang terjalin antara satu dengan yang lainnya sehingga masyarakat larut dalam kehangatan dan kegembiraan.

"jadi untuk anak muda rame-ramenya saja, apalagi ada deronya. Tapi sebenarnya yang tidak disadari dengan kita hadir dalam pesta Padungku berkunjung pada keluarga-keluarga kita itu berarti merajut kekerabatan.” Demikian ujar bue tini. (Diambil dari recmp3 durasi 34:19.50 wawancara mendalam dengan nenek Tini 14 Februari 2020).

Susanne K. Langger menyatakan kebutuhan simbolisasi atau penggunaan lambang merupakan salah satu kebutuhan pokok manusia dalam berkomunikasi, dan salah satu yang merupakan sifat dasar manusia adalah kemampuan menggunakan simbol Wiemen dan Walter (Johannesen 1996:46) dalam (Mulyana, 2013).

Itu sebabnya, peneliti menilai interaksi dan komunikasi yang terjadi dalam simbolisasi tradisi Padungku mampu menjembatani kedua belah pihak yang tegang akibat konflik poso sehingga mengurangi ketakutan, kekhawatiran, rasa saling curiga dan dendam karena seluruh masyarakat larut dalam suasana Padungku tersebut. Akhimya menghasilkan harmonisasi sosial masyarakat pasca konflik di Kabupaten Poso.

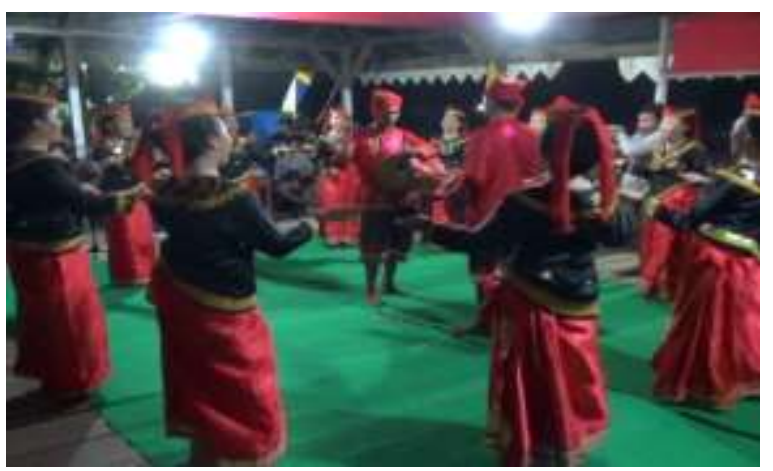

Gambar 3. Tarian Dero

Ada beberapa ritual yang dilakukan dalam proses pertanian dari awal sampai pesta panen Padungku. Hal itu dilakukan karena kehidupan suku pamona sangat erat hubungannya dengan kepercayaan adat dan ritual-ritual yang dilakukan merupakan cara suku pamona menghargai leluhurnya. Setelah mereka mengamati letak betu'e tamangkapa (rasi bintang orion) sudah tepat pada posisinya maka saatnya telah tiba untuk memulai kegiatan pertanian mereka diikuti ritual ritual yang mereka yakini mulai dari ritual lamoa, mesale, molanggo, mompaho, mangore dan Padungku. 
Ritual Lamoa adalah kepercayaan adat suku pamona dalam menghargai sang pencipta, ketika mengawali seluruh proses pertanian ritual ini wajib dilaksanakan. Ketika membuka suatu wilayah untuk pertanian pamali (sesuatu yang diharuskan) jika tidak dilakukan ritual Lamoa artinya kepercayaan ini dilakukan sebagai tanda penyembahan kita kepada sang pencipta.

"ketika mereka merasakan bahwa kehidupan apa yang mereka peroleh dari hasil pekerjaan ini, itu sebenarnya mereka mengucap syukur kepada Tuhan. Karna kalo dalam kepercayaan orang tua kita dulu ada tiga hal yang mereka katakan waktu itu bahwa ada yang mereka sembah tapi dengan istilah agama orang tua mo lamoa. Tiga dari kepercayaan mereka ini yang pertama itu bahasa poso itu pue mpalaburu jadi artinya Tuhan yang menciptakan langit dan bumi dan segala isinya. Kemudian ada pue toaralindo Tuhan yang mendukung semua ciptaan ini. Yang ketiga pue disongi itu Tuhan yang memelihara semua ciptaannya. Aa itu kepercayaan mereka waktu itu. Demikian penuturan ngkai Gimbaro. (Diambil dari recmp3 durasi 02:43.75 wawancara mendalam dengan kakek Gimbaro 19 Februari 2020).

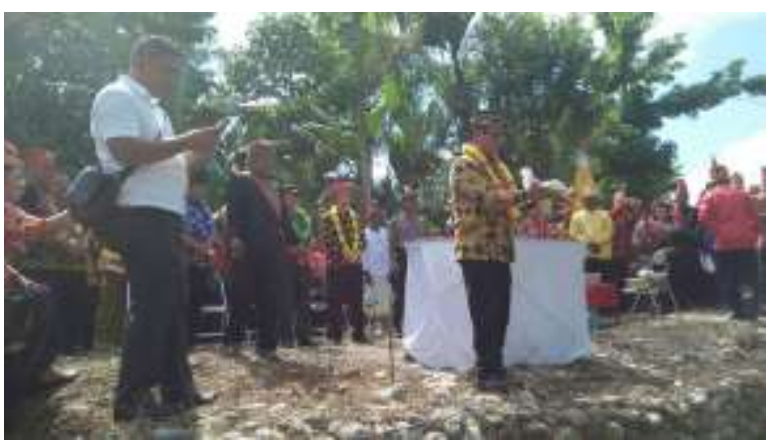

Gambar 4. Persembahan sesajen

Timbulnya ritual molamoa dimaknai oleh suku pamona sebagai penghormatan akan keberadaan sang pencipta walaupun suku pamona sebelum konflik meyakini Tuhan bersemayam dipohon besar. Tujuan dari ritual molamoa yaitu memohon ijin kepada penjaga alam untuk membuka lahan pertanian. Penghormatan kepada sang pencipta ditunjukan dalam ritual molamoa dimana suku pamona dipimpin oleh tadulako mempersembahkan sesajen dipohon-pohon besar dalam sesajen tersebut ada simbol-simbol khusus yang dimaknai bersama sebagai pesan yang ingin disampaikan oleh suku pamona bahwa mereka sangat menyadari ada sesuatu yang gaib yang tidak boleh diabaikan ketika akan melakukan sesuatu pada alam sehingga mereka mempergunakan alam dengan benar bukan malah merusak alam. Jika dalam ritual lamoa terjadi hal yang tidak beres seperti contoh tibatiba didatangi sekelompok lalat atau lebah artinya mereka tidak boleh membuka lahan didaerah tersebut dan harus mencari lahan lainnya.

Ritual mesale dilakukan secara berkelompok dengan memberikan tugas dan tanggung jawab pada masingmasing kelompok sampai semua pekerjaan selesai.

"jadi orang tua dulu itu semua bertani jadi kalo satu komunitas yang tinggal disitu, mereka kerja bersama membuka lahan bersama-sama. Kemudian kalo dulu orang tua itu kan biasa Cuma bikin rumah panggung jadi tidur itu yang keluarga disini seperti tinggal diantarai, kalo dulu dorang pake kelambu tapi kelambu dari kulit kayu jadi terpisah pisah itu keluarga disitu (tiap keluarga dipisahkan oleh kelambu). Jadi setelah dibuka ini lahan, kemudian lahan ini supaya bertanggung jawab masing-masing dibagi. Karena kalo secara umum saja mungkin tanggung jawabnya akan beda. Jadi misal sepuluh keluarga yang membuka lahan itu baku bantu, nah ini tanggung jawab kamu dan ini tanggung jawab kamu (tangung jawab dibagi perkelompok) supaya dalam kebersihan dan penjagaannya memang punya tanggung jawab disitu, jadi kalo secara keseluruhan ada yang baku harap kira-kira begitu (saling bergantung). Demikian penuturan ngkai Gimbaro. (Diambil dari recmp3 durasi 09:26.60 wawancara mendalam dengan kakek Gimbaro 19 Februari 2020).

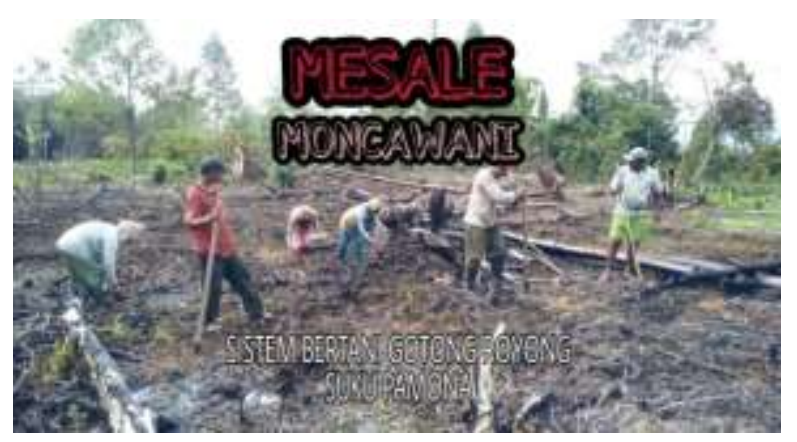

Gambar 3. Gotong royong membuka lahan

Dalam ritual Mesale, bermakna tanggung jawab kepada kelompok dalam mengelola lahan pertanian agar selalu kompak dan saling mendukung. Dengan mesale masyarakat mampu meyelesaikan pekerjaan pembukaan lahan pertanian dengan cepat secara bersama-sama, pembagian kelompok dalam pengerjaan suatu lahan pertanian dapat meringankan pekerjaan. Interaksi yang terjadi pada ritual mesale melahirkan simbol yang mendorong satu sama lain untuk tidak berleha-leha dalam menyelesaikan pekerjaan sehingga semuanya selesai tepat waktu. 
Ritual Molanggo adalah Prosesi adat sebelum penanaman padi yaitu acara adat yang dilaksanakan untuk persiapan sebelum melakukan penanaman esok hari. Molanggo identik dengan masak-memasak (untuk sajian makan bersama) menu khasnya adalah nasi dibungkus didaun makajoko, daging beko dan minuman khasnya Saguer yang selalu ada ditiap kesempatan selain itu juga, permainan ketangkasan mo winti (saling membanting kaki atau tangan) dan tari-tarian dero oleh anak perempuan. Permainan mo winti adalah permainan khas yang selalu dilakukan para anak muda laki-laki ketika acara molanggo.

"sebelum tanam padi, ada istilahnya molanggo. Molanggo ini katakanlah pesta adat dimana bahwa pada besok, tanah yang dibuka sudah bersih untuk ditanam padi, jadi istilahnya molanggo itu potong daging dimasak jadi orang datang makan disitu pancua daging dan minum saguer (arak). Ada permainan klo istilah dulu baku binti baku pasang kaki dipukul. Tujuan orang tua dulu kalo orang baku binti itu apa supaya tanaman itu bisa baisi (berisi) itu tanaman. Ada yang pake tangan ada yang pake kaki itu orang tua dulu pikir supaya tanaman itu punya isi. itulah maknanya molanggo itu. Demikian ujar ngkai Gimbaro. (Diambil dari recmp3 durasi 10:43.07 wawancara mendalam dengan kakek Gimbaro 19 Februari 2020).

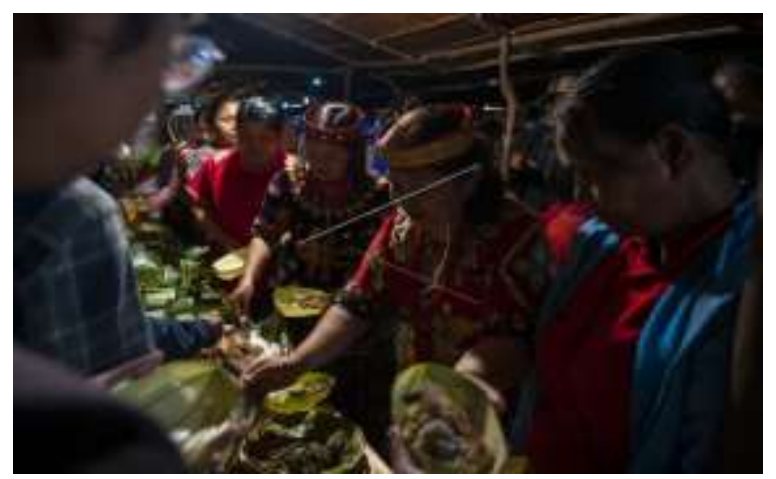

Gambar 4. Malam persiapan penanaman padi

Ritual molanggo, bermakna kesiapan dan semangat untuk melakukan pekerjaan esok hari dalam kegiatan penanaman padi ladang. Seluruh masyarakat yang terlibat dalam penanaman padi esok hari memanjakan diri mereka dengan jamuan makan, dan menimati kesenian dan tarian dimalam molanggo, penulis melihat interaksi yang terjalin dalam ritual molanggo mampu membangkitkan semangat para pekerja. mereka sadar besok akan melakukan pekerjaan yang cukup melelahkan untuk itu waktu persiapan ini dimanfaatkan dengan benar.

Ritual Mompaho merupakan ritual penanaman padi ladang yang dipimpin oleh seorang tadulako mpoja- maa. Prosesi penanaman padi ini diawali dengan menaikan doa dan penancapan kayu tugal oleh tadulako mpojamaa kedalam tanah sebagai simbol dimulainya proses penanaman. Setelah proses simbol dilakukan maka para pekerja langsung melakukan penanaman secara serentak.

"sampai disana, tadulako tadi ini juga akan menaikan doa sebelumnya. Doa mereka seperti ini "ooh pue mpalaburu (ooh Tuhan pencipta) sekarang anak-anakmu akan memulaikan ini dan seterusnya... dengan bahasa pamona meminta perlindungan. Kalo tadulako sudah ambe tugal dia yang akan tancap tugal pertama haa seterusnya dia tidak akan kerja terus yang penting tancapan pertama itu dia yang melakukan lalu dilanjutkan. Demikian ujar bue Tini. (Diambil dari recmp3 durasi 18:48.09 wawancara mendalam dengan nenek Tini 14 Februari 2020).

"prosesinya memang ada yang ditunjuk sebagai tadulako (Pimpinan) jadi dia harus duluan yang ba tugal baru diikut semua, karna yang ba tugal itu banyak orang kan. Demikian ujar ngkai Gimbaro. (Diambil dari recmp3 durasi 14:55.75 wawancara mendalam dengan kakek Gimbaro 19 Februari 2020).

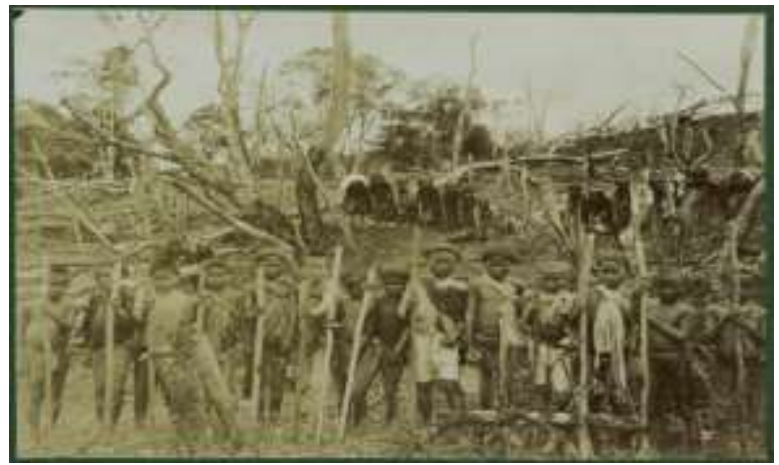

Gambar 5. Penugalan Tanah Menanam Padi

Ritual Mompaho bermakna kerjasama tim yang baik. Kegiatan penanaman yang dimulai dengan penugalan tanah yang dilakukan tadulako kemudian diikuti oleh para pekerja mulai dari laki-laki lalu pekerja wanita mengikuti dibelakang sampai selesai. Dalam hal ini penulis melihat bagaimana pesan yang disampaikan oleh tadulako dengan simbol menugal tanah tanda dimulainnya kegiatan penanaman padi mampu dijalankan sebagaimana mestinya sehingga tercipta keteraturan dalam proses penanaman padi. Terlihat juga bagaimana pekerja cakap dalam melanjutkan petunjuk pemimpin walaupun tadulako hanya menancapkan tugalnya sebanyak satu kali ketanah. Makna yang disepakati bersama membuat interaksi berjalan dengan baik. 
Ritual Mangore merupakan ritual syukuran kecil kepada Tuhan atas panen perdana padi yang dihasilkan. Ritual ini dilakukan sebelum melakukan acara syukuran besar atau Padungku Ritual ini dilakukan sebelum melakukan acara syukuran besar atau Padungku. Dalam syukuran ini yang menikmati acara ini hanya keluarga inti. Mereka menikmati hasil panen pertama dari tanaman yang mereka tanam sekaligus bersyukur kepada Tuhan atas panen perdana mereka dengan menaikan doa dan makan bersama.

"sebelum Padungku besar ada namanya mangore itu lingkungan keluarga saja. Setelah padi itu sudah dipetik kemudian dijemur setelah itu sudah ditumbuk, maka pertama-tama istilahnya mangore. Mangore ini berarti kita pertama memakan hasil pertama dari yang kita petik ini. Itu mangore dengan latarbelakang waktu itu namanya mangore juga yaitu mengucap syukur kepada Tuhan. Demikian ujar ngkai Gimbaro. (Diambil dari recmp3 durasi 17:12.40 wawancara mendalam dengan kakek Gimbaro 19 Februari 2020).

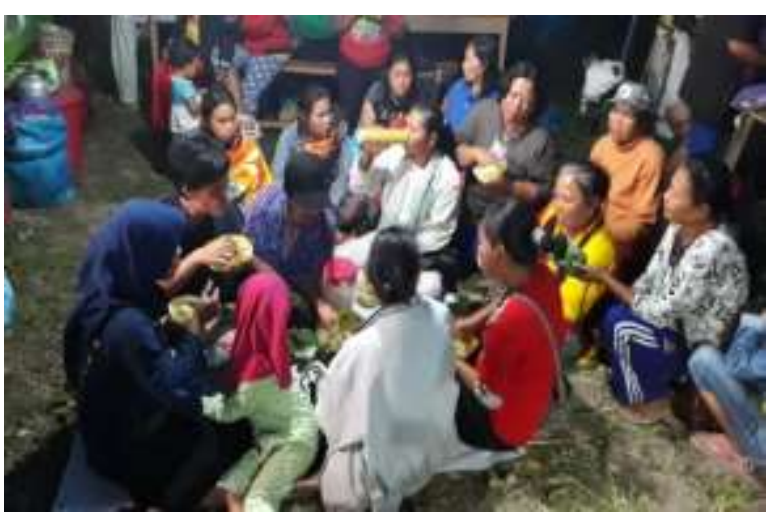

Gambar 6. Makan Padi Baru Hasil Panen

Ritual Mangore sebelum konflik bermakna ucapan syukur sederhana, hanya dilakukan sekelompok warga yang melakukan panen perdana. Dalam ritual ini ada simbol-simbol dalam tradisi mangore makan padi baru sebagai tanda syukur atas hasil panen. Penulis melihat dalam tradisi mangore masyarakat diajak untuk mensyukuri hasil kerja mereka, interaksi yang terjalin didalamnya memunculkan suasana kekeluargaan yang hangat, mereka bersyukur menjadi orang pertama yang menikmati hasil panen sebelum mereka melaksanakan syukuran besar.

Tradisi Padungku Setelah semua proses pertanian rampung, mulai dari pembukaan lahan hingga masa panen selesai yaitu padi telah semuanya di panen dan diisi ke dalam ala (lumbung padi) sebagai stok pangan selama setahun, dan peralatan pertanian telah dibersihkan maka akhir dari semua proses pertanian adalah pesta panen atau upacara Padungku.

"Padungku ini sudah direncanakan. Memang kalo sekarang beda kalo dulu Padungkunya begitu sudah kumpul dibaruga. Setelah dimasak itu nasi mo maso Padungku molimbu (berkumpul) disitulah dibagi sama-sama ada orang yang sudah masak daging, yang bagi kina'a (nasi), kemudian sayur dibelanga itu ditenteng-tenteng pake tangkau dibagi semua. Kalo dulukan masih banyak sapi masih banyak kerbau mo beko (lauk), kemudian sayur lain-lain kalo orang tua dulu lebih senang sayur rebus-rebus saja, kemudian ada yang disantan yang tidak ilang orang tua dulu $u w u$ (umbi silar) sayur $u w u$ dianggap makanan yang telah tersedia di alam jadi dorang tau manfaatkan ini. So ini salah satu makanan $u w u$ ini tidak bisa ilang dari acara acara pesta. Karna rasanya enak apalagi kalo disantan. Demikian ujar ngkai Gimbaro. (Diambil dari recmp3 durasi 31:24.33 wawancara mendalam dengan kakek Gimbaro 19 Februari 2020)

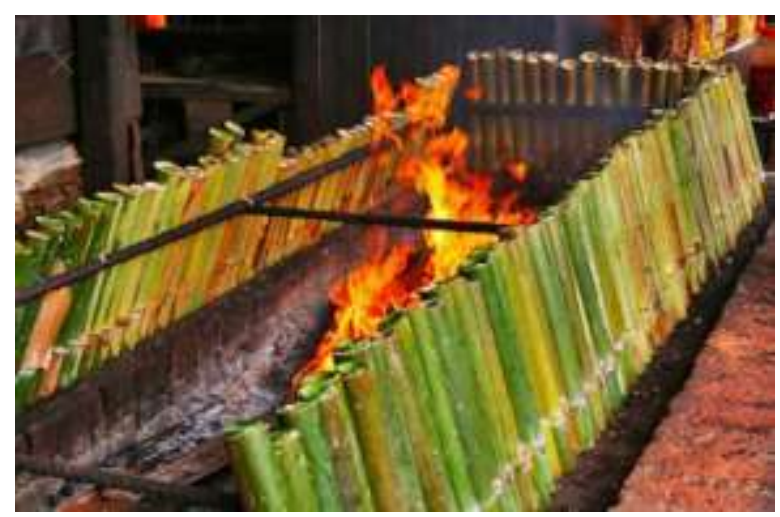

Gambar 7. Nasi Bambu (Inиyu)

Ritual Padungku sebelum konflik. ini adalah proses akhir dimana seluruh rangkaian pertanian telah selesai, padi telah masuk lumbung dan peralatan pertanian telah dibersihkan. Tradisi Padungku sebelum konflik dimaknai ungkapan syukur kepada sang pencipta atas penyertaan mulai dari pembukaan lahan hingga masa panen. penulis menilai tradisi Padungku merupakan ruang interaksi seluruh masyarakat untuk sama-sama bersyukur dan menikmati hasil panen terbukti mereka datang untuk sama sama menikmati hasil panen dalam satu tempat yaitu baruga (tempat pertemuan).

Makna pesan dalam rangkaian ritual Padungku tersebut tentunya sesuai dengan pernyataan Devito, ia mengatakan bahwa pemberian makna merupakan proses yang aktif karena makna diciptakan dengan 
kerja sama antara sumber dan penerima, pembicara dan pendengar, penulis dan pembaca. Dengan adanya interaksi antar manusia maka terbentuklah simbolsimbol yang memiliki makna (Devito, 1997)

Oleh karena itu, makna pesan simbolisasi tradisi Padungku sebelum konflik berpengaruh dalam pola berkelompok masyarakat suku pamona dan interaksi terjadi secara terus menerus sesuai makna didalamnya sehingga mampu menciptakan persatuan dan suasana yang harmonis.

\section{KESIMPULAN}

Dari penelitian mengenai pergeseran makna pesan tradisi Padungku dalam upaya harmonisasi masyarakat pasca konflik di Kabupaten Poso, maka dapat ditarik kesimpulan yakni didentifikasi simbolisasi tradisi Padungku terdiri dari 3 hal, yaitu: (1) Mosintuwu; (2) Mangkoni-mangkeni; (3) Modero. Dari setiap prosesi ritual suku pamona dalam tradisi Padungku, tersirat makna dan pesan melalui simbolisasi yang dilakukan. Makna dan pesan dalam simbolisasi tersebut suku pamona dan masyarakat yang berdiam Kabupaten Poso dapat terus menjaga persatuan, kepedulian, dan harmonisasi hingga tercipta kekuatan didalamnya sesuai dengan slogan Kabupaten Poso Sintuwu Maroso (Bersatu kita kuat). Dari pergeseran Makna pesan yang terkandung dalam ritual tradisi Padungku sebelum konflik, terlihat bagaimana tradisi ini membentuk keteraturan yang dibangun dalam kelompok, taat pada instruksi pimpinan, kebersamaan dalam melakukan tugas, bahu-membahu dalam setiap kegiatan, dan peduli terhadap sesama, serta tidak lupa untuk selalu mensyukuri hasil panen yang mereka peroleh dari Tuhan Yang Maha Esa.

\section{DAFTAR PUSTAKA}

Bugin, H. Burhan. 2006. Sosiologi Komunikasi: Teori, Paradigma, dan Diskursus Teknologi Komunikasi di Masyarakat. Jakarta: Kencana.

Cangara, Hafied. 2016. Pengantar Ilmu Komunikasi (Edisi Kedua). Jakarta: PT. RajaGrafindo Persada.

Kuswarno, Engkus. 2008. Etnografi Komunikasi. Bandng: Widya Padjadjaran.

Hasrulla, 2009. Dendam Konflik Poso (Periode 1998-201) Edisi Revisi. Jakarta: PT. Gramedia Pustaka Utama.

Creswll, Researh Design: Pendekatan Kualitatif, Kuantitatif, dan Mixed. Jogyakarta: Pustaka Pelajar.

Larry A. Samovar, Richard E. Porter dan Edwin R. McDaniel (Edisi 7). 2010. Communication Between Cultures. Jakarta: Salemba Humanika.

Richard West dan Lynn H. Turner. 2009. Pengantar Teori Komunikasi, (Edisi 3) Analisis dan Aplikasi Buku 1. Jakarta: Salemba Humanika.

Andi Nur Fitrah. 2019. Analisis Makna Pesan Nonverbal Paissangan Sumobal (Studi Komunikasi Etnografi Tehnik Pelayaran dan Navigasi Traditional Perahu Sandeq Suku Mandar).

Budianto, Adi. 2018. Tradisi Padungku Masyarakat Desa Maleku Kecamatan Mangkutana Kabupaten Luwu Timur: Sebagai Sumber Bahan Ajar Materi Geografi di SMA 4 Luwu.

Siti Hajar N. Aepu. 2014. Padungku Masih Bertahan Pada Etnis Bare'e di Desa Uedele Kecamatan Tojo Timur Kabupaten Tojo Una-una.

Tuti Bahfiarti. 2013. Pengelolaan Kesan Etnik Bugis dalam Adaptasi dengan Budaya Sunda. 